\title{
Phospholipid Synthesis by Rhodopseudomonas spheroides in Relation to the Formation of Photosynthetic Pigments
}

\author{
By JUNE LASCELLES AND J. F. SZILÁGYI \\ Microbiology Unit, Department of Biochemistry, University of Oxford
}

(Received 29 July 1964)

\begin{abstract}
SUMMARY
The concentration of phospholipids in pigmented Rhodopseudomonas spheroides was higher than that in organisms lacking the photosynthetic pigments; the amounts of lipid phosphorus/mg. protein were, respectively, 157 and 90 m $\mu$ moles. Phosphatidylethanolamine comprised about $40 \%$ of the phospholipids, the remainder consisting of phosphatidic acid, phosphatidylglycerol and phosphatidylcholine. The phospholipids were confined to the membrane fraction of the organisms. As organisms adapted from the non-pigmented to the pigmented state the amount of lipid phosphorus/mg. protein increased. Experiments with radioactive phosphate showed phosphatidyl glycerol to incorporate label more rapidly than the other phospholipids. It is suggested that the formation of the photosynthetic pigments may be accompanied by modifications to the membrane structure so that it can accommodate more phospholipids.
\end{abstract}

\section{INTRODUCTION}

The pigments of photosynthetic bacteria together with enzymes and cofactors required for photophosphorylation are located in relatively homogeneous particles termed chromatophores; these can be separated by differential centrifugation of cell-free extracts (Schachman, Pardee \& Stanier, 1953). In electron micrographs of sections of some photosynthetic bacteria the chromatophores appear as membranebound vesicles, the number of which varies with the degree of pigmentation (CohenBazire, 1963). In Athiorhodaceae grown aerobically, and consequently almost devoid of the pigments, few vesicles can be seen; they become more numerous and extend more deeply into the cytoplasm as the organisms increase in pigment content (Cohen-Bazire \& Kunisawa, 1963). There is now evidence that the vesicles are derived from the peripheral membrane and that the chromatophore fractions obtained from cell-free extracts arise by comminution of the membranes. Some electron micrographs of intact and lysed organisms have shown continuity between the vesicles and the peripheral membrane, suggesting that they may arise by invagination of this structure (Cohen-Bazire \& Kunisawa, 1963; Drews \& Giesbrecht, 1963; Boatman, 1964). Also, the photosynthetic pigments and photophosphorylation activity have been shown to reside in the 'ghost' fraction of Rhodospirillum rubrum disrupted by osmotic lysis (Tuttle \& Gest, 1959). The possibility that chromatophores arise from the peripheral membrane raises the question of whether adaptation of Athiorhodaceae from the non-pigmented to the pigmented state involves the synthesis of new membrane which contains the photosynthetic pig- 
ments incorporated into it. If so, it might be expected that pigmented organisms would contain a higher proportion of membrane than non-pigmented organisms.

In other types of bacteria there is abundant evidence that the phospholipids are largely confined to the membrane fraction (Kolb, Weidner \& Toennies, 1963; Robrish \& Marr, 1962) and the high content of phospholipids in chromatophore preparations again suggests their origin from the membrane (Newton \& Newton, 1957; Gibson, Neuberger \& Tait, 1962; Bull \& Lascelles, 1963). In the present work evidence for membrane synthesis associated with the development of photosynthetic pigments has been sought by following phospholipid synthesis in relation to bacteriochlorophyll formation in Rhodopseudomonas spheroides.

\section{METHODS}

Organisms. Rhodopseudomonas spheroides N.C.I.B. 8253 and the non-pigmented mutant strain L-70 were used. The latter was derived from the parent organism by repeated aerobic subculture on agar slopes and had completely lost the ability to form bacteriochlorophyll and carotenoids; it was therefore unable to grow anaerobically in the light.

Stock cultures were grown on malate + glutamate + yeast extract agar; cultures of the parent organism were maintained as stabs, grown in the light (Lascelles, 1956), while the mutant was kept on slopes incubated in the dark at $30^{\circ}$ for $24 \mathrm{hr}$.

Growth of cultures. Organisms were grown on the malate + glutamate medium aerobically in the dark or anaerobically in light, as described by Lascelles (1959). Organisms grown under the former conditions are termed 'non-pigmented' and under the latter as 'pigmented'.

Experiments with suspensions of organisms. Aerobic cultures were harvested at the end of the exponential phase and resuspended in phosphate-free medium ( $P$ medium). This was modified from the normal malate + glutamate medium (Lascelles, 1959) by omission of potassium and ammonium phosphates and by the

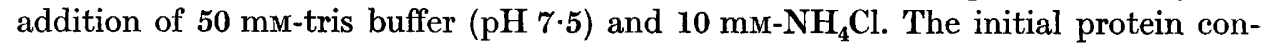
centration of the suspensions was $0 \cdot 8-1 \cdot 2 \mathrm{mg} . / \mathrm{ml}$. After addition of $\left[{ }^{32} \mathrm{P}^{2} \mathrm{KH}_{2} \mathrm{PO}_{4}\right.$ (mM; about $3 \mu \mathrm{c} . / \mathrm{ml}$.), suspensions were incubated under low aeration at $34^{\circ}$ as described previously (Lascelles, 1959). Samples were removed at intervals for determination of protein, lipid phosphorus and bacteriochlorophyll.

Determination of protein, bacteriochlorophyll and lipid phosphorus. Protein was determined by the method of Lowry, Rosebrough, Farr \& Randall (1951) after digestion of the organisms with $0.5 \mathrm{~N}-\mathrm{NaOH}$ at $100^{\circ}$ for $7 \mathrm{~min}$. The standard used was crystalline bovine plasma albumin, treated in the same way. Bacteriochlorophyll was estimated by the method of Cohen-Bazire, Sistrom \& Stanier (1957).

Lipid phosphorus was determined after extraction of lipids from acid-treated organisms or lysates with chloroform + methanol as follows. Samples of suspension or lysate equivalent to 10-20 mg. protein were treated with trichloroacetic acid $(5 \%, \mathrm{w} / \mathrm{v}$, final) and centrifuged. The pellet was suspended in $5 \%$ trichloroacetic acid $(10 \mathrm{ml}$.) and recentrifuged. The supernatant fluid was completely sucked off and the pellet homogenized with $5 \mathrm{ml}$. chloroform + methanol $(2+1$, by vol.). After centrifugation, the supernatant fluid was removed and the pellet re-extracted with $5 \mathrm{ml}$. chloroform + methanol. The combined supernatant fluids were made to a 
known volume (10-15 ml.) and represented the extracted lipids. Total phosphorus was determined on $0.5-1.0 \mathrm{ml}$. samples of this extract by the method of Bartlett (1959).

Distribution of phosphorus in phospholipids. The proportion of the various phospholipids in the extracted lipids was determined by methods based on those used by Dawson (Dawson, 1960; Dawson, Hemington \& Davenport, 1962) and by Gray \& MacFarlane (1964). In principle, the phospholipids were deacylated by mild alkaline hydrolysis; the water-soluble deacylated compounds were separated by paper chromatography and estimated by determination of phosphorus after elution.

Samples (4-6 ml.; 0.25-1.0 $\mu$ mole phosphorus) of the chloroform +methanol extract prepared as above were shaken twice with an equal volume of $2 \mathrm{M}-\mathrm{KCl}$ and once with water; after each treatment the aqueous layer was removed. The washed extract was taken to dryness under an air stream at $60^{\circ}$. The residue was dissolved in $0.4 \mathrm{ml}$. chloroform and $0.6 \mathrm{ml}$. methanolic $\mathrm{NaOH}(0 \cdot 1 \mathrm{~N})$ added. The mixture was incubated at $37^{\circ}$ for 20 min., neutralized with $\mathrm{N}-\mathrm{HCl}$, and taken to dryness under an air stream. The residue, consisting of unsaponifiable lipid, free fatty acids and deacylated phospholipids, was shaken with $1 \mathrm{ml}$. of the upper phase and $2 \mathrm{ml}$. of the lower phase of a mixture containing chloroform + methanol + water $(27+13+$ 10 by vol.). The aqueous phase, containing the deacylated phospholipids, was removed and freeze-dried. The product was dissolved in $0.2 \mathrm{ml}$. water and $0.04 \mathrm{ml}$. applied to Whatman paper No. 1 which had been washed with $2 \mathrm{~N}$-acetic acid. Descending chromatography was used, the solvents being either water-saturated phenol+acetic acid+ethanol $(100+10+2$ by vol., Dawson, 1960) or watersaturated phenol containing $0 \cdot 1 \%$ (v/v) ammonia sp.gr. $0 \cdot 88$ (Kanfer \& Kennedy, 1963).

The developed chromatograms were sprayed with ninhydrin to reveal the compound corresponding to phosphatidylethanolamine. In samples labelled with ${ }^{32} \mathrm{P}$ the phosphorus-containing compounds were made visible by radioautography on Kodak 'Blue Brand' X-ray film (4-24 hr exposure). Non-radioactive samples were run beside labelled samples and the phosphorus-containing areas delineated by extrapolation.

Elution was as follows. The areas containing phosphorus were cut out and rolled in aluminium foil allowing about $1 \mathrm{~mm}$. of paper to show at one end; the rolls were fixed to the top of conical centrifuge tubes with adhesive tape and about 5 drops of water applied to the top edge of the paper. The tubes were centrifuged for about 1 min., the eluate collecting at the bottom of the tube; this procedure was repeated twice more. The total phosphorus of the eluates was determined by the method of Bartlett (1959).

Measurement of radioactivity. The colour developed after treatment of the eluates by the Bartlett method was measured spectrophotometrically. The solutions were then transferred to a thin glass-walled liquid counter, Type M6M (Panax Equipment Ltd., Surrey) and the radioactivity determined using an Ekco automatic scaler Type N530D (Ekco Electronics Ltd., Essex). Results are expressed as counts/ 100 sec. (minus background)/m $\mu$ mole phosphorus.

Materials. ${ }^{32} \mathrm{P}$ was obtained from the Radiochemical Centre, Amersham, Buckinghamshire; it was in the form of carrier-free orthophosphate. 


\section{RESULTS}

Phospholipid content of pigmented and non-pigmented organisms

Rhodopseudomonas spheroides $\mathbf{8 2 5 3}$ grown anaerobically in the light and therefore containing the photosynthetic pigments had 50-70\% more phospholipid than did non-pigmented organisms grown with high aeration. The mutant organism, which does not form photosynthetic pigments, contained about the same amount of lipid phosphorus as the parent strain grown in the non-pigmented state (Table 1).

The difference in phospholipid content between the pigmented and non-pigmented forms of the parent organism was reflected in the rate of phospholipid synthesis by cultures growing photosynthetically and aerobically (Fig. 1). The differential rate (ratio of increase in phospholipid to increase in protein) was about 1.8 times higher in the photosynthetic culture, and this difference was maintained throughout the growth curve.

The proportion of individual phospholipids was determined on the deacylated products as described in the methods. When samples containing ${ }^{32} \mathbf{P}$ were subjected to radioautography four major radioactive spots were detected. The $R_{F}$ values in the phenol + acetic acid + ethanol solvent were: $0.35,0.51,0.66$ (ninhydrin-positive) and about $0 \cdot 9$. These values corresponded to the deacylation products of, respectively, phosphatidic acid, phosphatidylglycerol, phosphatidylethanolamine and phosphatidylcholine (Dawson et al. 1962). Phosphatidylethanolamine predominated, comprising about $40 \%$ of the total phospholipids; this pattern of phospholipids was found in both pigmented and non-pigmented $R$. spheroides 8253 and in the mutant organism (Table 1 ). Identification of these phosphatides was also confirmed by other methods (Szilágyi \& Lascelles, to be published).

\section{Location of lipid phosphorus in membrane fraction}

Treatment of Rhodopseudomonas spheroides $\mathbf{8 2 5 3}$ with lysozyme in the presence of EDTA resulted in rapid lysis and within $5 \mathrm{~min}$. few if any intact organisms were visible microscopically. Centrifugation of the lysates, after treatment with DNAase to render them less viscous, resulted in a pellet fraction containing all the photosynthetic pigments. This pellet presumably is derived largely from the cytoplasmic membrane though the presence of cell-wall fragments cannot be excluded. Analysis of lipid phosphorus in the washed pellet fraction showed that more than $90 \%$ was located in the pellet derived from both pigmented and non-pigmented organisms (Table 2). It can therefore be concluded that the phospholipids of $R$. spheroides, as in other bacteria, are largely confined to the particulate or membrane fraction of the organisms.

\section{Phospholipid synthesis by suspensions of Rhodopseudomonas spheroides}

Phospholipid synthesis was studied with suspensions of aerobically grown $\boldsymbol{R}$. spheroides during adaptation to form photosynthetic pigments under conditions of low aeration (Lascelles, 1959). Over a period of $3 \mathrm{hr}$ the lipid phosphorus content/mg. protein increased by about $1 \cdot 7$-fold, while the bacteriochlorophyll content increased by about 200-fold (Fig. 2a). Suspensions of the mutant strain of $\boldsymbol{R}$. spheroides, which does not form pigments, were incubated under the conditions 
Table 1. Phospholipid content of Rhodopseudomonas spheroides 8253 and L-70

The mean values for lipid phosphorus are from analyses of four different batches of organisms grown under the various conditions; the range is shown in brackets. The distribution of lipid phosphorus in the various phospholipid fractions is the result of one analysis in each case.

\begin{tabular}{|c|c|c|c|}
\hline \multirow{2}{*}{$\begin{array}{c}\text { Strain no. } \\
\mathbf{8 2 5 3}\end{array}$} & \multirow[b]{2}{*}{$\begin{array}{c}\text { Growth conditions } \\
\text { Anaerobic } \\
\text { in light } \\
\text { Aerobic } \\
\text { in dark }\end{array}$} & \multicolumn{2}{|c|}{$\begin{array}{l}\text { Bacteriochlorophyll Lipid phosphorus } \\
\text { (m } \mu \text { moles } / \mathrm{mg} \text {. protein) }\end{array}$} \\
\hline & & $\begin{array}{l}44 \\
\quad(36-48) \\
0 \cdot 48 \\
(0 \cdot 44-0 \cdot 56)\end{array}$ & $\begin{array}{l}157 \\
(144-172) \\
90 \\
(73-105)\end{array}$ \\
\hline L-70 & $\begin{array}{l}\text { Aerobic } \\
\text { in dark }\end{array}$ & n.d. & $\begin{array}{l}82 \\
(69-97)\end{array}$ \\
\hline
\end{tabular}

\begin{tabular}{cccc}
\multicolumn{4}{c}{ Distribution of lipid phosphorus* $(\%)$} \\
$\begin{array}{c}\text { Phosphatidyl- } \\
\text { ethanolamine }\end{array}$ & $\begin{array}{c}\text { Phosphatidic } \\
\text { acid }\end{array}$ & $\begin{array}{c}\text { Phosphatidyl- } \\
\text { choline }\end{array}$ & $\begin{array}{c}\text { Phosphatidyl- } \\
\text { glycerol }\end{array}$ \\
40 & 24 & 22 & 14 \\
39 & 28 & 20 & 13 \\
41 & 24 & 21 & 14
\end{tabular}

n.d. $=$ not detectable

$*=$ as $\%$ of total phosphorus recovered after chromatography of the deacylated lipids.

Table 2. Distribution of lipid phosphorus in lysed preparations of Rhodopseudomonas spheroides $\mathbf{8 2 5 3}$

Suspensions of organisms containing 140-200 mg. protein were incubated for $15 \mathrm{~min}$. at $34^{\circ}$ in the presence of (final conc.): tris buffer ( $\mathrm{pH} 8 \cdot 6$ ), $0.1 \mathrm{~m}$; EDTA, $5 \mathrm{~mm}$; lysozyme, $0.5 \mathrm{mg} . / \mathrm{ml} . \mathrm{MgSO}_{4}(10 \mathrm{~mm})$ and $\mathrm{DNA}$-ase $(5 \mu \mathrm{g} . / \mathrm{ml}$.) were then added and the mixture incubated for $5 \mathrm{~min}$. longer. Samples $(2 \mathrm{ml}$.) were removed for determination of lipid phosphorus on the whole lysate. The remainder was centrifuged for $1 \mathrm{hr}$ at $100,000 \mathrm{~g}$; the pellet was resuspended in $20 \mathrm{ml}$. water and centrifuged again. The washed pellet was suspended in $20 \mathrm{ml}$. water and samples taken for determination of lipid phosphorus.

\begin{tabular}{|c|c|c|c|c|c|}
\hline \multirow[b]{2}{*}{ Expt. } & \multirow[b]{2}{*}{$\begin{array}{c}\text { Type of } \\
\text { organisms }\end{array}$} & \multirow[b]{2}{*}{$\begin{array}{c}\text { Total protein } \\
\text { of suspension } \\
\text { (mg.) }\end{array}$} & \multicolumn{2}{|c|}{$\begin{array}{l}\text { Total lipid phosphorus } \\
\text { ( } \mu \text { moles) }\end{array}$} & \multirow{2}{*}{$\begin{array}{c}\text { Lipid phos- } \\
\text { phorus } \\
\text { recovered } \\
\text { in pellet } \\
(\%)\end{array}$} \\
\hline & & & $\begin{array}{l}\text { Whole } \\
\text { lysate }\end{array}$ & $\begin{array}{c}\text { Pellet } \\
\text { fraction }\end{array}$ & \\
\hline 1 & Pigmented & 162 & $24 \cdot 2$ & $22 \cdot 4$ & 93 \\
\hline 2 & Pigmented & 139 & $24 \cdot 6$ & 24.7 & 100 \\
\hline 3 & Non-pigmented & 202 & $22 \cdot 2$ & $20 \cdot 3$ & 92 \\
\hline
\end{tabular}


which promoted pigment formation by the parent organism. Though phospholipid synthesis occurred it was matched by the increase in protein and consequently the amount of lipid phosphorus/mg. protein did not change (Table 3).

To determine whether there were differences in the rate of synthesis of the various phospholipids under these conditions, experiments were done with [ $\left.{ }^{32} \mathrm{P}\right]$ phosphate. The specific activity of the deacylated lipids was determined after separation by

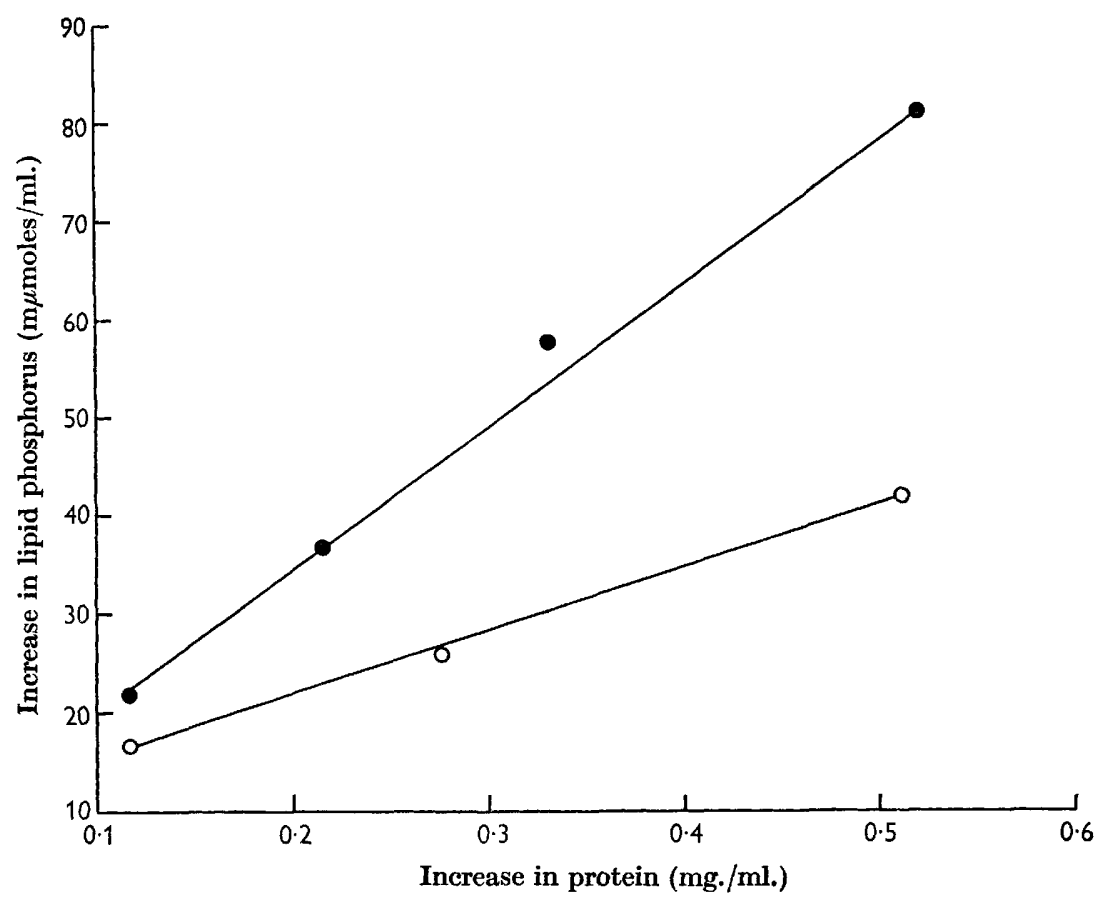

Fig. 1. Differential rate of phospholipid synthesis by cultures of Rhodopseudomonas spheroides 8253 growing anaerobically in the light (๑) and aerobically in the dark (O).

paper chromatography. Phosphatidylglycerol increased in radioactivity at a more rapid rate than the other phospholipids; phosphatidylcholine was formed at the slowest rate (Fig. $2 b$ ). This pattern of incorporation of ${ }^{32} \mathbf{P}$ into the phospholipids was, however, not uniquely associated with pigment synthesis. The same rapid incorporation into phosphatidylglycerol occurred with suspensions of the parent organism incubated under high aeration which represses pigment synthesis. Also, the mutant strain showed the same pattern of labelling as the parent organism when incubated under comparable conditions (Table 3).

\section{DISCUSSION}

The concentration of phospholipid in Rhodopseudomonas spheroides is of the same order as that found in other Gram-negative organisms; values varying from about 90 to $180 \mathrm{~m} \mu$ moles lipid phosphorus/mg. protein have been found in a variety of non-photosynthetic organisms (MacFarlane, 1964; Kaneshiro \& Marr, 1962). The pattern of phospholipids found in $R$. spheroides is also not unique; phosphatidyl- 
ethanolamine is the predominant phosphatide in many bacteria, though the occurrence of phosphatidylcholine is less common (MacFarlane, 1964). The experiments with suspensions of $R$. spheroides with [ $\left.{ }^{32} \mathrm{P}\right]$-phosphate suggest that phosphatidylglycerol is the most metabolically active of the phospholipids. In growing cultures

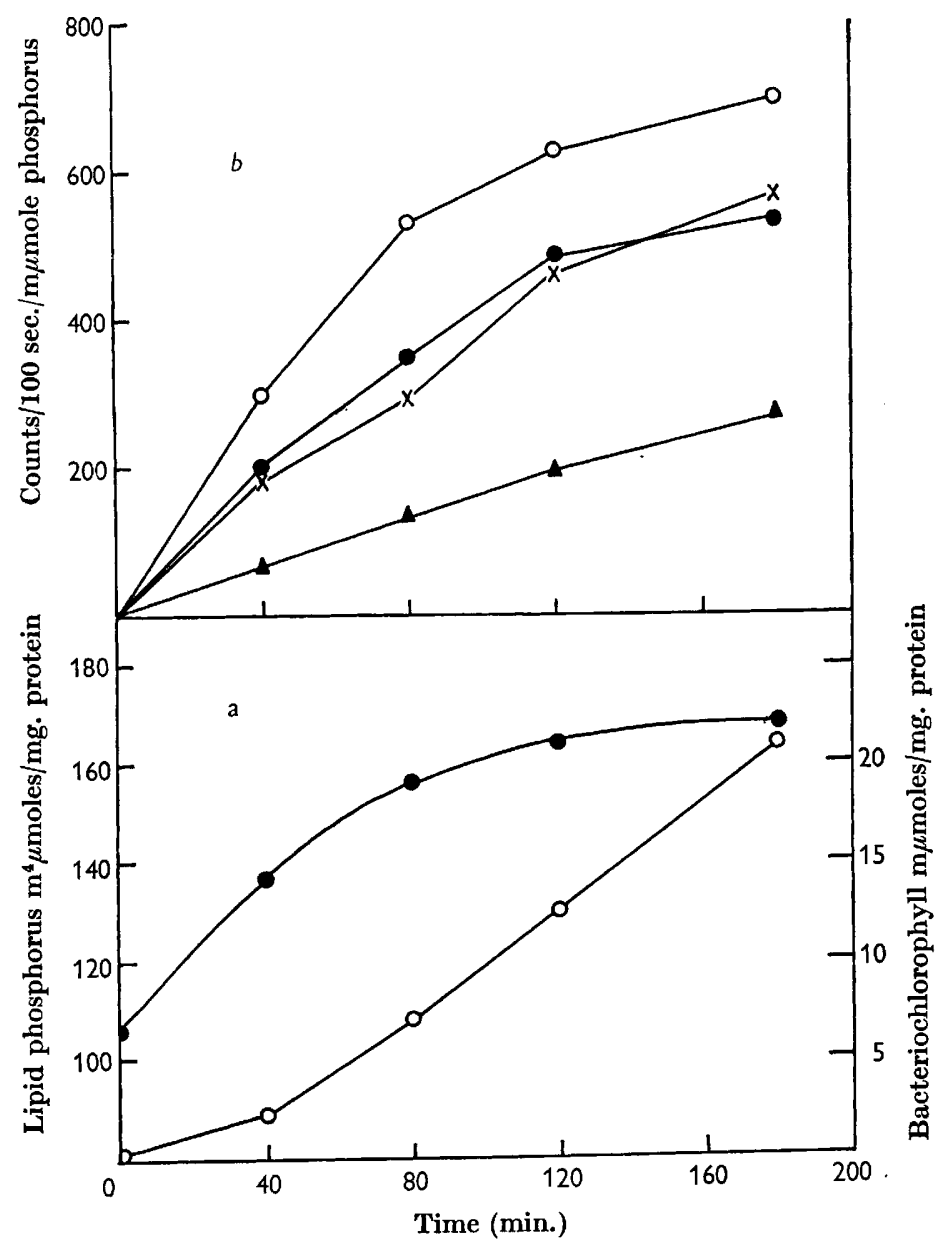

Fig. $2 a, b$. Synthesis of phospholipids and bacteriochlorophyll by suspensions of $R$. spheroides 8253 under low aeration. Aerobically grown organisms were suspended in P-medium supplemented with $\left[{ }^{32} \mathrm{P}\right] \mathrm{KH}_{2} \mathrm{PO}_{4}(1 \mathrm{mM} ; 3 \mu \mathrm{c} / \mathrm{ml}$. $)$ The suspensions were incubated under low aeration and samples removed at intervals for the determination of lipid phosphorus (O) and bacteriochlorophyll (O) (Fig. 2a). The deacylated phospholipids were separated by paper chromatography and the specific radioactivity determined as described in the Methods (Fig. 2b). Phosphatidylglycerol, $O$; phosphatidic acid, phosphatidylethanolamine, $x$; phosphatidylcholine, $\Delta$. Initial protein conc. $=0.8 \mathrm{mg}$./ ml.; after $120 \mathrm{~min} ., 1.4 \mathrm{mg} . / \mathrm{ml}$.

of Escherichia coli this phosphatide is subject to rapid turnover suggesting again that it plays some dynamic metabolic role, which has yet to be established (Kanfer \& Kennedy, 1963).

Since the phospholipids are located in the membrane fraction of Rhodopseudo- 
Table 3. Phospholipid synthesis by suspensions of Rhodopseudomonas spheroides 8253 and L-70

Suspensions of aerobically grown parent (8253) and mutant (L-70) organisms were incubated under low or high aeration in -P medium supplemented with $\left.{ }^{32} \mathrm{P}\right] \mathrm{KH}_{2} \mathrm{PO}_{4}(1 \mathrm{~mm} ; 2 \cdot 4 \mu \mathrm{c} / \mathrm{ml}$.) Analyses were made as described in Fig. 2.

\begin{tabular}{|c|c|c|c|c|c|c|c|c|}
\hline \multirow{2}{*}{$\begin{array}{c}\text { Strain no } \\
\mathbf{8 2 5 3}\end{array}$} & \multirow{3}{*}{$\begin{array}{l}\text { Incubation conditions } \\
\text { Nil } \\
\text { High aeration; } 40 \mathrm{~min} . \\
\text { High aeration; } 120 \mathrm{~min} . \\
\text { Low aeration; } 120 \mathrm{~min} .\end{array}$} & \multirow{3}{*}{$\begin{array}{c}\begin{array}{c}\text { Protein } \\
\text { (mg./ml.) }\end{array} \\
\mathbf{1 . 2 5} \\
\mathbf{1 . 3}\end{array}$} & \multirow{2}{*}{\multicolumn{2}{|c|}{$\begin{array}{c}\begin{array}{c}\text { Bacterio- } \\
\text { chlorophyll } \\
\text { (m } \mu \text { moles/mg. protein) }\end{array} \\
\begin{array}{c}\text { Lipid } \\
\text { phosphorus }\end{array}\end{array}$}} & \multicolumn{4}{|c|}{ Specific activity (counts/100 sec./m $\mu$ mole phosphorus } \\
\hline & & & & & $\begin{array}{c}\text { Phosphatidyl- } \\
\text { glycerol } \\
-\end{array}$ & $\begin{array}{c}\text { Phosphatidic } \\
\text { acid } \\
-\end{array}$ & $\begin{array}{c}\text { Phosphatidyl- } \\
\text { ethanolamine } \\
- \\
93\end{array}$ & \multirow{2}{*}{$\begin{array}{c}\text { Phosphatidyl- } \\
\text { choline } \\
- \\
\mathbf{6 3}\end{array}$} \\
\hline 8253 & & & $\begin{array}{l}0 \cdot 22 \\
0 \cdot 34 \\
0 \cdot 32 \\
6 \cdot 3\end{array}$ & $\begin{array}{r}73 \\
82 \\
95 \\
122\end{array}$ & $\begin{array}{l}\overline{367} \\
496 \\
515\end{array}$ & $\begin{array}{r}- \\
\mathbf{9 1} \\
\mathbf{3 8 7} \\
\mathbf{3 7 0}\end{array}$ & $\begin{array}{r}- \\
93 \\
342 \\
375\end{array}$ & \\
\hline L-70 & $\begin{array}{l}\text { Nil } \\
\text { Low aeration; } 40 \mathrm{~min} \text {. } \\
\text { Low aeration; } 120 \mathrm{~min} .\end{array}$ & $\begin{array}{l}0 \cdot 85 \\
0 \cdot 95 \\
1 \cdot 4\end{array}$ & $\begin{array}{l}0 \\
0 \\
0\end{array}$ & $\begin{array}{l}81 \\
81 \\
87\end{array}$ & $\begin{array}{l}\overline{345} \\
676\end{array}$ & $\begin{array}{r}\overline{90} \\
294\end{array}$ & $\begin{array}{r}- \\
880\end{array}$ & $\begin{array}{r}\overline{50} \\
179\end{array}$ \\
\hline
\end{tabular}


monas spheroides the higher concentration found in pigmented organisms might suggest that pigment formation is associated with increased membrane formation. Such an interpretation would be consistent with the results of electron microscopy. However, there are other observations that do not support this. In both $R$. spheroides and Rhodospirillum rubrum the proportion of protein in the particulate fraction (assumed to be derived from the membrane) is similar in extracts from pigmented and non-pigmented organisms (Cohen-Bazire \& Kunisawa, 1960; Sistrom, 1962; Bull \& Lascelles, 1963). As suspensions of non-pigmented $\boldsymbol{R}$. spheroides adapt to form bacteriochlorophyll protein synthesis occurs, but the distribution of protein between the soluble and particulate fractions remains the same (Bull \& Lascelles, 1963). Thus, there is no evidence for a higher proportion of membrane protein in pigmented organisms, though the membrane fraction is apparently richer in phospholipid. Possibly, the pigmented organisms have a membrane structure differing from that in non-pigmented organisms in that it accommodates more phospholipid; this may serve as a medium for orientation of the hydrophobic pigment molecules. The problem of how the extra phospholipids and the photosynthetic pigments become incorporated into the membrane structure as organisms adapt from the non-pigmented to the pigmented state now requires to be answered. Perhaps the preferential turnover of protein in the particulate fraction that accompanies the adaptation (Bull \& Lascelles, 1963) may represent some form of differentiation of the membrane into a lipid-enriched form.

Phospholipids may play an important role in all structures associated with electron transport. They comprise about $20 \%$ of the dry weight of preparations of respiratory particles from bacteria and their importance in mitochondrial electron transport is well established (Green \& Fleischer, 1963). Studies of mitochondrial substructure have suggested that phospholipids are bound to a structural protein matrix as well as to the electron transport particles which are thought to be attached to the matrix (Richardson, Hultin \& Green, 1963). Whether this concept can be extended to the photosynthetic and electron transport systems of bacteria requires fractionation of the complexes combined with cytological studies.

We are greatly indebted to Dr Marjorie G. MacFarlane for information and advice, and to Miss L. Butler and Miss P. Conibear for skilled technical assistance. J. F. S. is grateful for a grant from the Central Fund for Hungarians, administered by the University of London. We wish to thank the Department of Scientific and Industrial Research for a grant towards research expenses. The research was also assisted by grants to the Department from the Rockefeller Foundation and the United States Department of Health, Education and Welfare.

\section{REFERENCES}

Bartlett, G. R. (1959). Phosphorus assay in column chromatography. J. biol. Chem. $234,466$.

Boatman, E. S. (1964). Observations on the fine structure of spheroplasts of Rhodospirillum rubrum. J. cell. Biol. 20, 297.

Bull, M. J. \& Lascelles, J. (1963). The association of protein synthesis with the formation of pigments in some photosynthetic bacteria. Biochem. J. 87, 15. 
Cohen-Bazire, G. (1963). Some observations on the organization of the photosynthetic apparatus in purple and green bacteria. In: Bacterial Photosynthesis, p. 89. Ed. by H. Gest, A. San Pietro \& L. P. Vernon. Antioch Press: Yellow Springs, Ohio.

Comen-Bazire, G. \& Kunisawa, R. (1960). Some observations on the synthesis and function of the photosynthetic apparatus in Rhodospirillum rubrum. Proc. nat. Acad. Sci., Wash. 46, 1543.

Cohen-Bazire, G. \& Kunisawa, R. J. (1963). The fine structure of Rhodospirillum rubrum. J. cell. Biol. 16, 401.

Cohen-Bazire, G., Sistrom, W. R. \& Stanier, R. Y. (1957). Kinetic studies of pigment synthesis by non-sulfur purple bacteria. J. cell. comp. Physiol. 49, 25.

Dawson, R. M. C. (1960). A hydrolytic procedure for the identification and estimation of individual phospholipids in biological samples. Biochem. J. 75, 45 .

Dawson, R. M. C., Hemington, N. \& Davenport, J. B. (1962). Improvements in the method of determining individual phospholipids in a complex mixture by successive chemical hydrolyses. Biochem. J. 84, 497 .

Drews, G. \& Giesbrecht, P. (1963). Zur Morphogenese der Bakterien-'Chromatophoren' (Thylakoide) und zur Synthese des Bacteriochlorophylls bei Rhodopseudomonas spheroides und Rhodospirillum rubrum. Zbl. Bakt. (1. Abt. Orig.) 190, 508.

Gibson, K. D., Neuberger, A. \& Tait, G. H. (1962). Studies on the biosynthesis of porphyrin and bacteriochlorophyll by Rhodopseudomonas spheroides. I. Effect of growth conditions. Biochem. J. 83, 550.

Gray, G. M. \& Macfarlane, M. G. (1964). On the identification of phosphatidylethanolamine in pigeon breast muscle. Biochem. J. 91, $16 \mathrm{C}$.

Green, D. E. \& Fleischer, S. (1963). The role of lipids in mitochondrial electron transfer and oxidative phosphorylation. Biochim. biophys. Acta, 70, 554.

Kaneshiro, T. \& Marr, A. G. (1962). Phospholipids of Azotobacter agilis, Agrobacterium tumefaciens and Escherichia coli. J. Lipid Res. 3, 184.

Kanfer, J. \& Kennedy, E. P. (1963). Metabolism and function of bacterial lipids. I. Metabolism of phospholipids in Escherichia coli B. J. biol. Chem. 238, 2919.

Kolb, J. J., Weinner, M. A. \& Toennies, G. (1963). Microdetermination of lipid phosphorus as a measure of bacterial membrane substance. Analyt. Biochem. 5, 78.

LASCELles, J. (1956). The synthesis of porphyrins and bacteriochlorophyll by cell suspensions of Rhodopseudomonas spheroides. Biochem. J. 62, 78.

LASCElles, J. (1959). Adaptation to form bacteriochlorophyll in Rhodopseudomonas spheroides: changes in the activity of enzymes concerned in pyrrole synthesis. Biochem. J. 72, 508.

Lowry, O. H., Rosebrough, N. J., Fark, A. L. \& Randall, R. J. (1951). Protein measurement with the Folin phenol reagent. J. biol. Chem. 193, 265.

Macfarlane, M. G. (1964). The phospholipids of bacterial membranes. (In the Press.)

Newton, J. W. \& Newton, G. A. (1957). Composition of the photoactive subcellular particles from Chromatium. Arch. Biochem. Biophys. 71, 250.

Richardson, S. H., Hultin, H. O. \& Green, D. E. (1963). Structural proteins of membrane systems. Proc. nat. Acad. Sci., Wash. 50, 82.

Robrish, S. A. \& MARr, A. G. (1962). Location of enzymes in Azotobacter agilis. J. Bact. $83,158$.

Schachman, H. K., Pardee, A. B. \& Stanier, R. Y. (1953). Studies on the macromolecular organization of bacterial cells. Arch. Biochem. Biophys. 38, 245.

Sistrom, W. R. (1962). Observations on the relationship between formation of photopigments and the synthesis of protein in Rhodopseudomonas spheroides. J. gen. Microbiol. 28, 599.

TutTle, A. L. \& Gest, H. (1959). Subcellular particulate systems and the photochemical apparatus of Rhodospirillum rubrum. Proc. nat. Acad. Sci., Wash. 45, 1261. 